\title{
ADMINISTRATIEVE VRAAGSTUKKEN EIGEN AAN INTERNATIONALE MAATSCHAPPIJEN
}

\author{
door P. C. Breek
}

\section{INLEIDING}

Het is voor de hoogste leiding van grote industriële ondernemingen, die opereren in vele landen, een vanzelfsprekendheid dat decentralisatie van bevoegdheden naar lagere niveaus van management noodzakelijk is om aan het initiatief, de drang tot vernieuwing en de flexibiliteit zo veel mogelijk ruimte te bieden. Daarbij blijken er verschillen te bestaan in de wijze waarop deze internationale ondernemingen organisatorisch gestructureerd zijn; hiervoor bestaan oorzaken van subjectieve en objectieve aard.

In de subjectieve sfeer liggen instelling en geaardheid van de hoogste leiding. In dit verband maakt men wel onderscheid tussen autocratisch en democratisch leiderschap. Prof. Likert (V.S.) gebruikt hiervoor de meer sprekende termen taakgericht en mensgericht leiderschap ${ }^{1}$ ). Ook kunnen mentaliteitsverschillen bij de medewerkers in de landen waar men is gevestigd een rol spelen; men denke o.a. aan de verschillende cultuurpatronen in de onderscheidene geografische gebieden. Voorts zal blijken dat binnen het kader van een formeel decentralisatiepatroon, informele varianten optreden die ook nauw samenhangen met karakter en persoonlijkheid van de leiders der gedecentraliseerde eenheden. In dit veld van krachten zal er steeds een harmonie, of zo men wil een compromis, tot stand komen tussen centraliserende en decentraliserende tendensen.

Economische wetmatigheden en organisatorische beginselen zijn meer objectieve faktoren, die naast de aard en gecompliceerdheid van het produktie- en afzetproces, hun invloed doen gelden op de organisatiestructuur.

Wat de economische wetmatigheden betreft zij gewezen op de invloed van de wet van de comparatieve kostenverschillen op de internationale arbeidsverdeling binnen de onderneming. Deze wet impliceert dat de verdeling van het produktiepakket over de produktieplaatsen zodanig zal geschieden dat de kosten van de totale produktie worden geminimaliseerd. In de evaluering van de comparatieve kostenverschillen behoort het verband tussen kostprijs en seriegrootte in aanmerking te worden genomen. Centralisatie van gelijksoortige produktieprocessen stelt immers in staat door verbetering van de kwantitatieve verhoudingen en een gunstiger gebruikscoëfficiënt de „economies of scale" te realiseren. Opgemerkt dient echter te worden dat de belangen van de nationale economieën - met name vóór de tot standkoming van grotere economische eenheden als E.E.G., E.F.T.A. en L.A.F.T.A. - een beperkende invloed uitoefenen op de mogelijkheden van de internationale arbeidsverdeling binnen de onderneming. Een wezenlijke taak van de hoogste leiding is ook hier om - met volledige inachtneming van mogelijke nationale belangen - voortdurend te werken aan de meest gewenste oplossing voor de onderneming als geheel.

De noodzaak tot lokale affiniteit en flexibiliteit, in concreto het zich snel en constructief kunnen aanpassen aan de zich steeds wijzigende omstandigheden, leidt, zoals gezegd, in het algemeen tot een verregaande delegatie van bevoegd-

1) Prof. Dr. R. Likert: New patterns of management 1961. 
heden. In een gedecentraliseerde organisatiestructuur is het evenwel noodzakelijk om met betrekking tot de hoofdzaken eenheid van beleid te handhaven. In de Leer van de Organisatie wordt in dit verband vaak gewezen op het beginsel van de handhaving van de ,unity of command". Tegen de achtergrond van het complexe karakter van een internationale onderneming is het wellicht beter te spreken van de noodzaak tot handhaving van de ,unity of purpose” gebaseerd op een integraal beleidsprogramma.

Bij de af weging van voor- en nadelen van alternatieve gradaties van decentralisatie en het zoeken naar een optimale organisatiestructuur, is de automatisering van de informatieverwerking een faktor van grote betekenis aan het worden. Deze zou zelfs kunnen leiden tot vrij ingrijpende wijzigingen in de organisatiestructuur.

Automatisering kan in combinatie met nieuwe telecommunicatietechnieken resulteren in een verbeterde centrale coördinatie, n.l. in die gevallen waarin men door gebrek aan goede informatie voorheen moest decentraliseren. Anderzijds kunnen de bevoegdheden in sterkere mate gedelegeerd worden - onder voorbehoud van beslissingen die uitzonderlijke aandacht vragen - omdat mogelijkheden zijn gecreëerd in het informatiecircuit voor betere en snellere "exception reporting". Zowel de „span of control" als de „span of attention" van de leiding der onderneming zullen door de nieuwe informatietechnieken in samenhang met de automatisering een wijziging ondergaan en wel zodanig dat de effectiviteit van de leiding wordt vergroot. ${ }^{2}$ )

$\mathrm{Er}$ is reeds gesteld dat de mate waarin in een onderneming de bevoegdheden op bevredigende wijze overgedragen kunnen worden aan landsorganisaties voor een groot deel ook afhankelijk is van de aard en gecompliceerdheid van het bedrijfsproces. In het algemeen zal het bij ondernemingen met een groot assortiment van technisch gecompliceerde produkten noodzakelijk zijn om kennis te centraliseren. Dit houdt in, dat zulke ondernemingen geneigd zijn om centraal research- en produktmanagement-groepen op te stellen. De organisatorische consequenties zijn, dat zowel op het gebied van produktie als van verkoop de landsorganisaties en de centrale produktenorganisaties gezamenlijk bevoegdheden resp. verantwoordelijkheden hebben. Daarentegen zal in ondernemingen, waar de bedrijfsproblematiek zich vooral concentreert op de afzet, het mogelijk zijn om in meerdere mate bevoegdheden en verantwoordelijkheden te decentraliseren naar de landsorganisaties.

Welke structurering van funkties en organen men ook heeft gekozen, steeds zullen voorzieningen in het vlak van de communicatie moeten worden getroffen welke het mogelijk maken het besturingsproces, dat door de geografische spreiding extra wordt bemoeilijkt, zo goed mogelijk te doen verlopen.

Deze voorzieningen in het vlak van de communicatie zullen op twee fronten gericht moeten zijn, te weten:

1 de beleidsvorming en beslissingsvoorbereiding (oordeelsvorming ex-ante);

2 de verificatie van het beleid en de besluitvorming (oordeelsvorming ex-post).

In dit kader heeft de administratieve funktie tot taak informatie te verzamelen, te verwerken en te verstrekken. Zowel met betrekking tot de besluitvorming als tot de verificatie van het beleid is het noodzakelijk dat de administratie naast retro-

2) Span of control. Het aantal ondergeschikten dat onder de leiding van één persoon kan worden geplaatst.

Span of attention. De heterogeniteit van werkzaamheden welke een grote spreiding van aandacht veroorzaakt en daardoor invloed heeft op de effectiviteit van de leiding. 
spectieve informatie ook prospectieve informatie verschaft. Bij een systematische opzet van de prospectieve informatie spelen het meerjarenplan en het budget een belangrijke rol. De retrospectieve informatie is de berichtgeving over het werkelijk bedrijfsgebeuren. Deze informatie krijgt haar betekenis voor de oordeelsvorming ex-post in belangrijke mate door de confrontatie met plannen en budgetten.

De normatieve beoordelingsmaatstaven waarop een doelmatige administratieve informatieverstrekking dient te zijn gebaseerd, zijn te vinden in de bedrijfseconomische wetenschap. De bedrijfseconomische inzichten hebben reeds in belangrijke mate invloed op de in het maatschappelijk verkeer anvaardbare normen uitgeoefend en onder invloed van de evolutie der bedrijfseconomie zullen de bedrijfseconomische inzichten verder in deze maatschappelijke normen doorwerken. Wij zijn derhalve van mening dat ten behoeve van de externe verslaglegging dezelfde bedrijfseconomische grondslagen dienen te worden gehanteerd als bij de interne verslaglegging. Voor de internationale onderneming waar men met een verscheidenheid van fiscale en andere wettelijke regimes te maken heeft, waar men met zoveel varianten van acceptabele ,accounting principles" wordt geconfronteerd is het van essenticel belang wèlke bedrijfseconomische principes en methoden men zal hanteren voor een verantwoorde en consistente voorlichting van het management en de verslaggeving t.b.v. het maatschappelijk verkeer. ${ }^{3}$ ) Wij stellen ons daarom voor, in

\section{Hoofdstuk II: Enkele bedrijfseconomische grondslagen}

te behandelen. Vanuit het streven naar continuïteit zal men de vraag moeten beantwoorden welke grondslagen men dient te hanteren voor de waardering en winstbepaling, waar de grenzen liggen tussen winstbepaling en winstbestemming en welke voorzieningen moeten worden gevormd. Daarbij zal tevens aandacht worden besteed aan de problematiek verbonden met de winstbepaling en de criteria voor beleidsbepaling en beleidsbeoordeling.

\section{Vervolgens zullen wij onze aandacht richten op}

\section{Hoofdstuk 1II: Het valutaprobleem}

Niet alleen ter wille van de vaststelling van de geconsolideerde jaarrekening, maar ook ter wille van een juiste berichtgeving over de aktiviteiten en de resultaten in de onderscheidene organisaties zal aandacht worden besteed aan de problematiek van de valutakoersen.

\section{Hoofdstuk IV: De aansluiting van de informatie op de organisatie}

Als gevolg van de internationale structuur van de onderneming ontstaan problemen op het gebied van de berichtgeving over aktiviteiten en resultaten, o.a. veroorzaakt door het bestaan van onderlinge leveranties. Voors zullen worden behandeld problemen verband houdend met de prospectieve informatie, de invloed van de financiering, de betekenis van economische blokvorming, de toerekening van de kosten van het centrale beheersapparaat en de consolidatie, de betekenis van bedrijfsvergelijkingen, benevens indoctrinatie, training en opleiding van administratieve medewerkers. Tenslotte behandelen wij dan in

3) De interpretatie van het begrip maatschappelijk verkeer dient hier te worden beperkt tot economisch verkeer. 


\section{Hoofdstuk V: De invloed van de automatisering}

Hierin wordt in een korte schets aandacht besteed aan het begrip automatisering, soorten van informatie, fasen in de automatisering, de invloed van automatisering op de besturing en op de organisatie van de onderneming.

\section{ENKELE BEDRIJFSECONOMISCHE GRONDSLAGEN}

Door Ir. Otten ${ }^{4}$ ) werd in zijn rede, uitgesproken bij de opening van het achtste internationale accountantscongres te New York, de doelstelling van de onderneming als volgt geformuleerd:

„Formerly this (the objective of the enterprise) was considered to be the pure striving for profits to which everything else was subordinated more or less. In the development of the economy it has become abundantly clear that our efforts should be directed not at maximum short term profits but rather at the most appropriate profit applicable to the continuity of the undertaking. The evolution in the social field shown in the continuous improvement in terms of employment and in social relationships within the enterprise has caused the social aspect to become an important element in the policy considerations of management with regard to that continuity."

Met inachtneming van de doeleinden van de onderneming zal door de leiding voortdurend een keuze worden gemaakt uit diverse mogelijkheden van actie. In het geheel van overwegingen zal de economische afweging van opbrengsten en te brengen offers een belangrijke rol spelen. Wil de administratie haar functie als informatieverstrekkend orgaan goed vervullen, dan zal zij in het bijzonder haar informatie over het bedrijfsgebeuren moeten funderen op de verworvenheden van de bedrijfseconomische wetenschap. Met name zal zij ten behoeve van de afweging van opbrengsten en offers gebruikmaken van de bedrijfseconomische grondslagen voor waarde- en winstbepaling.

\section{Waarde- en winstbepalingsgrondslagen}

Reeds decennia lang - met een onderbreking gedurende de crisis in de dertiger jaren - gaat economische groei gepaard met een van land tot land verschillend tempo van inflatoire ontwikkeling.

Veel experts zijn van mening dat dit ook in de toekomst een begeleidend verschijnsel zal zijn van de economische vooruitgang.

Ter illustratie van de inflatie vermelden wij voor enige landen de gemiddelde jaarlijkse muntdepreciatie ${ }^{5}$ ) over de perioden $1955-65$ en 1964-656).

\footnotetext{
4) Destijds president van de N.V. Philips' Gloeilampenfabrieken te Eindhoven, Nederland.

5) The shrinkage in the value of money is measured, reciprocally by increases in official indexes of consumer prices or the cost of living.

6) Ontleend aan Monthly Economic Letter, First National City Bank, New York, July Issue 1966.
}

m a b blz. 6 


$\begin{array}{lrr} & 1955 / 65 \% & 1964 / 65 \% \\ \text { Argentinië } & 23.4 & 22.3 \\ \text { Brazilië } & 29.7 & 38.2 \\ \text { Frankrijk } & 4.6 & 2.4 \\ \text { Groot Brittannï } & 3.0 & 4.6 \\ \text { Nederland } & 3.0 & 5.0 \\ \text { Verenigde Staten } & 1.7 & 1.7 \\ \text { West-Duitsland } & 2.2 & 3.3\end{array}$

Tegen deze achtergrond is het duidelijk dat waardering en calculatie op basis van historische prijzen irreëel is. Met betrekking tot de winstbepaling ontstonden dan ook reeds na de $1 \mathrm{e}$ wereldoorlog tal van stelsels, zoals het ijzeren voorraadstelsel en het lifo-stelsel, waarmede men althans ten dele de inflatoire vermogensaanwas - die niet als werkelijk gemaakte winst kan worden beschouwd - wilde elimineren. Het voornaamste bezwaar tegen deze stelsels is dat zij geen integrale conceptie van waardering ten behoeve van de winstbepaling en de bepaling van het vermogen bieden. Hierdoor wordt het onmogelijk op uniforme prijsgrondslag gefundeerde relaties te bepalen tussen winst en vermogen (return on capital), terwijl het criterium ,return on capital" juist van zo bijzonder groot belang is, niet alleen voor de beleidsbepaling en de beleidsbeoordeling van de totale onderneming, maar ook voor het vergelijken van het vermogen en de resultaten van de deelactiviteiten en landsorganisaties. Indien men in aanmerking neemt dat de voor deze activiteiten in de diverse organisaties werkende produktiemiddelen op verschillende tijdstippen tegen verschillende prijzen werden angeschaft, wordt de noodzaak tot het volgen van een uniforme gedragslijn extra benadrukt.

$\mathrm{Bij}$ de hantering van de waardebegrippen zoals deze zijn ontwikkeld in de theorie van de vervangingswaarde wordt het wèl mogelijk relaties te bepalen tussen winst en vermogen, omdat zowel de waardering bij de resultatenbepaling, als de waardering van het vermogen geschiedt tegen uniforme waardegrondslagen. De theorie van de vervangingswaarde geeft de faktoren aan, die de hoogte van de waarde in het maatschappelijk verkeer bepalen op een actueel moment, n.l. het moment waarop de waardering plaats vindt. Als zodanig sluit de conceptie van de vervangingswaarde ook aan bij de instelling van de entrepreneur, wiens denken en handelen immers is gericht op vandaag en morgen. Voor een onderneming waarvoor handhaving van de continuïteit als een praemisse wordt aanvaard, zal de vervangingswaarde dan ook bepalend zijn voor het waarde-oordeel.

Wanneer over het vraagstuk van de winstbepaling wordt gesproken is het van belang hierbij op te merken, dat we dan spreken over de bepaling van winst over een periode, ter onderscheiding van de transactie-winsten, waaronder we dan verstaan het voordeel met ieder van de afzonderlijke transacties verkregen.

Het transactie-voordeel wordt gevormd door het gunstig verschil van opbrengstwaarde en vervangingswaarde van het bij de ruil overgedragen goed of dienst, beide waarden bepaald op het moment van de ruil. Indien hier de ruil gekozen wordt als kritisch moment voor de waardering is dit om een doelbewuste scheiding te maken tussen de resultaten van het verkoopbeleid en van voorraadbeleid; dit is tevens een van de essentialia van de theorie van de vervangingswaarde. Als gevolg van het voorraadbeheer en de voor-en nadelige resultaten die 
daaruit kunnen voortvloeien, benevens afwijkingen tussen ex-ante schattingen en ex-post waarnemingen van technische en economische slijtage, efficiencyverschillen door afwijkingen van kostenstandaards en verschillen in bedrijfsdrukte, is de periode-winst niet gelijk aan de som van de transactie-resultaten. De sommering van de transactie-resultaten leert ons dus wel de vermogenstoeneming kennen, welke door de ruiltransacties in deze periode wordt verkregen, maar in hoeverre deze toeneming voor uitkering vatbaar is, wordt mede bepaald door de in voorgaande zin vermelde factoren. De uitkeerbaarheid wordt derhalve gemeten aan de periode-winst en niet aan de transactie-winst.

Zonder thans in te gaan op alle details van de vervangingswaardetheorie ${ }^{7}$ ) willen wij nog wijzen op de consequentie van waardewijzigingen in voorraden en vaste activa. Ter handhaving van de continuïteit wordt nl. een vermogensaanwas als gevolg van prijsstijgingen in de onderneming gehouden en is derhalve niet voor uitkering vatbaar (men spreekt hier wel eens van schijnwinsten). De consequentie is dus deze; voorraden staan gewaardeerd tegen vervangingswaarde, verschillen met historische uitgaafprijs worden ten gunste, resp. ten laste van een vermogensmutatierekening herwaardering gebracht.

Als gevolg van de gestelde praemisse handhaving van de continuïteit, dient ook de grootte van het eigen vermogen in overeenstemming te worden gebracht met de gewijzigde koopkrachtverhoudingen, indien nominale middelen geheel of gedeeltelijk worden gefinancierd uit eigen vermogen.

Om deze reden zullen eventuele verliezen wegens koopkrachtvermindering van het in nominale middelen geïnvesteerde eigen vermogen ten laste van de resultatenrekening moeten worden gebracht.

\section{Grenzen van winstbepaling en winstbestemming}

Op basis van de hiervoor in dit hoofdstuk beschreven grondslagen beoogt men tot een zodanige winstbepaling te komen, dat op het bruto-inkomen over een afgelopen periode alle offers in mindering zijn gebracht die nodig zijn om de onderneming in haar huidige omvang te handhaven.

Onvoldoende kennis van de mogelijke toekomstige ontwikkelingen, m.a.w. het niet beschikken over verfijnde waarnemingsinstrumenten, zal ons in de loop van een periode bij de waarnemingen noodzaken tot schattingen over te gaan. Deze schattingen als subjectief aan te merken en ze als zodanig te zien als winstbestemmingselementen, zou echter de indruk wekken, alsof deze schattingen afhankelijk zouden zijn van persoonlijk inzicht. Het vaststellen van vaste gedragsregels voor het bepalen dezer offers - zoals dynamisch bepaalde voorzieningen en de bepaling van de levensduur van duurzame produktiemiddelen - doen deze offers echter niet meer afhankelijk zijn van multi-individueel inzicht. Derhalve zouden we het vaststellen van de hoogte dezer offers niet als subjectief willen bestempelen, maar in voldoende mate geobjectiveerd. Bovendien kan men zich op het moment van de winstbepaling op dan in beginsel beter bekende faktoren baseren met betrekking tot de afgelopen periode. Beperken wij dus de winstbepaling tot de afgelopen periode en verklaren het hiermede tot een ex-post begrip, dan is er inderdaad sprake van een afbakening, een afbakening gebaseerd op doelmatigheidsgronden.

7) Zie voor een uiteenzetting over deze theorie "The sixth international congress on accounting, 1952 Fluctuating price levels in relation to accounts by A. Goudeket”.

m a b blz. 8 
De winstbestemming zien wij als een ex-ante begrip, waarbij zodanige winstinhoudingen worden gepleegd als met het oog op toekomstige ontwikkeling en de continuïteit nodig worden geacht.

In een expanderende economie is groei een voorwaarde voor het voortbestaan van een onderneming. De offers noodzakelijk voor de financiering van de groei zou men eveneens weer kunnen betrekken binnen het terrein van winstbepaling. Deze offers onttrekken zich echter aan de beoordeling van en beïnvloeding door de lagere niveau's van leiding, omdat de financiering in een onderneming sterke centrale accenten heeft.

Men zou zich kunnen voorstellen dat deze financieringslasten dan in de geconsolideerde resultatenrekening worden opgenomen, zonder een specificatie naar lands- of produktgroepen. Op grond van de voorgaande motiveringen gebaseerd op doelmatigheidsgronden achten wij ook deze winstinhoudingen als ex-ante grootheden te behoren tot het terrein van de winstbestemming.

Bovendien komt men door deze begrenzingen van winstbepaling en winstbestemming tot een uniform begrippen-apparaat, dat voor de diverse lands- en produktgroeporganisaties niet afwijkt van het voor de totale onderneming geldende winstbegrip en dat bovendien is aanvaard in het maatschappelijk verkeer.

\section{Dynamisch bepaalde voorzieningen}

Bij haar keuzehandelingen neemt de leiding risico's inhaerent aan de bedrijfsvoering in aanmerking en tracht deze te evalueren. Risico's effectueren zich op een onzeker tijdstip in de vorm van een offer, welke het karakter kan hebben van een uitgaaf of een verminderde opbrengst. Daar de risico's permanent aanwezig zijn tijdens de gehele cyclus van de kapitaalcomponenten en de produktcyclus - en derhalve daarmede complementair verbonden zijn - is de consequentie dat de met de risico's verbonden offers over de gehele cyclustijd behoren te worden gespreid.

Voorbeelden van dergelijke risico's zijn de schade, die ontstaat wanneer debiteuren niet aan hun verplichtingen voldoen of als ingekochte of geproduceerde goederen later incourant blijken te zijn. Indien men dergelijke schaden op het moment dat zij zich manifesteren in de resultatenrekening zou opnemen, zou deze een verkeerd inzicht geven in het gevoerde beleid, aangezien men structurele consequenties van bedrijfsvoering bestempelt tot incidenten. Het is daarom gewenst in de kostprijs en daardoor in de resultatenrekening de met behulp van empirisch materiaal geschatte offers verbonden aan de risico's op te nemen. Uit de aldus dynamisch gevormde voorzieningen kunnen dan de incidenteel optredende offers worden bestreden.

Met het vormen van dynamische voorzieningen bereiken wij:

- De kostprijs zal beter kunnen fungeren als steunpunt voor de bepaling van de verkoopprijs, resp. als richtsnoer voor de keuze uit alternatieve acties.

- De resultatenrekening wordt niet vertroebeld door incidenten, waardoor de winstgevendheid van de bedrijfshandelingen beter kan worden beoordeeld.

- De waardering van het geïnvesteerde vermogen houdt rekening met de risico's verbonden aan het bezit van kapitaalgoederen. 


\section{Fiscale invloeden}

$\mathrm{Bij}$ de voorgaande behandeling van de bedrijfseconomische grondslagen voor waardering en winstbepaling is de invloed van de fiscale wetgeving buiten beschouwing gebleven. Daar de fiscale winstopvatting vrijwel nooit overeenkomt met de bedrijfseconomische winstopvatting, wordt de reële belastingdruk op de bedrijfseconomische winst in het algemeen niet door het wettelijke tarief tot uitdrukking gebracht. Ook kan men niet uitgaan van het bedrag aan te betalen belastingen, omdat dit in het geheel geen verband behoeft te houden met de bedrijfseconomische winst over de periode waarop de betaling betrekking heeft. Voor de vaststelling van de reële belastingdruk zal dan ook het wettelijke belastingtarief moeten worden gecorrigeerd met de extra druk die het gevolg is van de afwijkende winstopvattingen.

De divergenties in de winstopvattingen behoeven zich niet te beperken tot de waarderingsgrondslagen (zoals de door de fiscus dikwijls niet erkende toepassing van de vervangingswaardetheorie) doch kunnen ook betrekking hebben op verliezen als gevolg van de koopkrachtvermindering van in nominale middelen geinvesteerd eigen vermogen of op fiscaal niet aftrekbare uitgaven.

Afwijkingen die niet méér betekenen dan een verschuiving van de belastingheffing in de tijd kunnen zowel leiden tot een vervroegde heffing als tot een uitgestelde heffing van de winstbelasting. Men spreekt dan wel van het ontstaan van latente aanspraken, respectievelijk verplichtingen.

Als meest voorkomende oorzaken zijn te noemen:

- vervroegde afschrijvingen

- dynamische voorzieningen

- verschillen in levensduurtermijnen en afschrijvingssystemen.

Ook wanneer de mogelijkheid bestaat een fiscaal verlies te compenseren met toekomstige winsten, ontstaat er op het moment dat het fiscale verlies optreedt een latente winstbelastingaanspraak. Zou men immers met deze aanspraak geen rekening houden dan zou er in het jaar van effectieve compensatie van de verliezen een discrepantie ontstaan tussen het bedrijfseconomische resultaat en de daarop drukkende belastingen.

Als gevolg van de latenties komt de vraag naar voren of een compensatie van aanspraken en verplichtingen zonder meer is geoorloofd.

Men dient hierbij te bedenken dat het voor het realiseren van een latente aanspraak vereist is dat er althans binnen de verliescompensatie-termijn voldoende fiscale winsten moeten zijn waarmede het basisbedrag van de aanspraak kan worden verrekend.

Dit vereiste geldt niet voor de latente verplichtingen. Hieruit volgt dat men de aanspraken conservatiever zal moeten waarderen dan de verplichtingen. Ook dient men rekening te houden met de opbouw naar vervaltermijnen van de aanspraken en verplichringen.

Indien men voorgaande opmerkingen in de beschouwing van de latenties betrekt, dan achten wij voor de balanswaardering een compensatie van deze aanspraken en verplichtingen, zowel nationaal als internationaal verantwoord. 


\section{Criteria voor beleidsbepaling en beleidsbeoordeling}

Criteria voor beleidsbepaling en beleidsbeoordeling zullen moeten worden geformuleerd tegen de achtergrond van de doelstellingen van de onderneming. Deze doelstellingen zijn deels economisch, deels niet-economisch van aard. Wij willen ons conformeren aan enige opvattingen van Ansoff ${ }^{8}$ ). Deze onderzoeker heeft het volgende opgemerkt:

- In most firms the economic objectives exert the primary influence on the firm's behavior and form the main body of explicit goals used by management for guidance and control of the firm.

- The central purpose of the firm is to maximize long term return on resources employed within the firm.

- The social objectives exert a secondary modifying and constraining influence on management behavior.

De bedrijfshandelingen zijn gericht op conversie van produktiefaktoren in goederen en diensten (,the resource conversion process"). Vanuit de economische gezichtshoek zal dit proces zo doelmatig mogelijk moeten geschieden omdat continuïteitshandhaving als voorwaarde stelt dat het in de onderneming werkzame vermogen tot een optimale rentabiliteit wordt gebracht.

Deze stelling kan in twee betekenissen worden opgevat. Richt men zijn aandacht op het totale in de onderneming werkzame vermogen dan bestaat de opbrengst uit het zogenaamde bedrijfsresultaat, dat is de winst voor aftrek van aan derden betaalde rente en winstbelasting.

Richt men zijn aandacht daarentegen op het in de onderneming werkzame eigen vermogen, dan is het relevant, de netto winst, dat wil zeggen de winst na aftrek van betaalde rente derden en winstbelasting daaraan te relateren. Deze laatste relatie is vooral voor de aandeelhouder interessant.

Het verband tussen de beide rentabiliteitsopvattingen kan als volgt in de bekende rentabiliteitsformule worden samengevat:

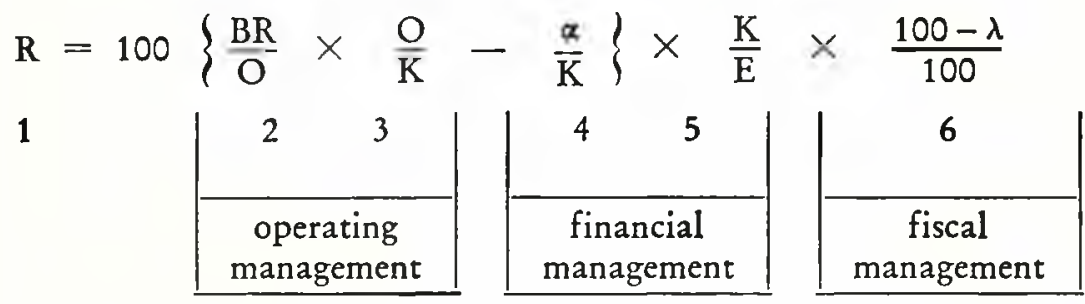

$\mathbf{R}=$ netto winst in $\%$ van het eigen vermogen

$\mathrm{BR}=$ bedrijfsresultaat, d.w.z. winst voor aftrek van rente derden en winstbelasting

$\mathrm{O}=$ omzet

$\mathrm{K}=$ totaal kapitaal $=$ totaal vermogen

$\alpha=$ aan derden betaalde rente

$\mathrm{E}=$ eigen vermogen

$\lambda=$ calculatiepercentage winstbelasting

8) H. J. Ansoff Corporate Strategy, 1965, $241 \mathrm{blz}$. 
Deze formule geeft de samenhang weer tussen de faktoren die de rentabiliteit beïnvloeden, te weten winstmarge (2), omloopsnelheid (3), aan derden betaalde rente (4) vermogensstructuur (5) en winstbelasting (6).

Het informatiespectrum van de administratie behoort gericht te zijn op al deze parameters en wel zodanig dat elk niveau van leiding c.q. elke categorie van leiders die informatie ontvangt welke aansluit op hun verantwoordelijkheidsgebied.

De informatie aan het operating management - waaronder wij verstaan de verschillende niveaus van commerciële en technische leiding - zal gericht zijn op de faktoren 2 en 3 uit de formule, welke tezamen de ratio ,return on capital" representeren.

Financieringsinvloeden moeten hier in eerste aanleg buiten beschouwing blijven omdat zij, zoals verder ${ }^{9}$ ) nog uitvoerig zal worden aangetoond, buiten de directe invloedssfeer van het operating management vallen, alhoewel ze evenals de fiscale invloeden bij het nemen van beleidsbeslissingen in aanmerking dienen te worden genomen door het ,operating management”.

De informatie aan het financiële management is toegespitst op de kosten van de financiering en de financiële structuur, dat zijn de faktoren 4 en 5 . Tenslotte zal het fiscale management geïnformeerd worden over de winstbelasting.

Hantering van de rentabiliteitsformule in deze zin opent de mogelijkheid een zinvolle differentiatie aan te brengen in de informatie voor de verschillende categorieën van leiders. Dit klemt temeer omdat de behoefte aan detailinformatie voor de onderscheiden categoriën van leiders aanmerkelijk verschilt.

De informatie over winstmarge en omloopsnelheid aan het operating management moet in sterke mate worden gedetailleerd naar verantwoordelijkheidsgebieden, artikelengroepen, afzetkanalen, afnemerscategorieën enz. De informatie aan het financial management zal in veel mindere mate worden gedetailleerd, terwijl de informatie over de winstbelastingdruk praktisch alleen per land gedifferentieerd zal worden. Uitdrukkelijk zij hier nog eens gewezen op het grote belang, voor het operating management om wèl de invloed van de financiering en de winstbelastingdruk in de verschillende beleidsbeslissingen te betrekken. Dit kan fiscaal zowel betrekking hebben op de keuze van het moment, waarop een besluit wordt uitgevoerd, als op de wijze waarop men een bepaalde beleidsmaatregel uitvoert en met name de juridische vorm welke men ervoor kiest. De operationele leiding zal dan ook bij vraagstukken die een fiscaal aspect zouden kunnen hebben, tijdig belastingdeskundigen dienen in te schakelen.

De hantering van deze formule is niet beperkt tot de retrospectieve beleidsverificatie, maar in minstens van evenveel betekenis bij de prospectieve beleidsinformatie.

De bepaling van de rentabiliteit op de bovengeschetste wijze en de vergelijkingsmogelijkheden die binnen en buiten de onderneming ontstaan, openbaren „strengths and weaknesses". Zo komt duidelijk naar voren dat de winstmarge van zelfgefabriceerde artikelen mag afwijken van inkoopartikelen, die weinig kapitaal vergen, terwijl deelactiviteiten met lage rentabiliteit evenals verschillen tussen geografische gebieden, afzetkanalen en afnemerscategorieën zichtbaar worden.

9) Pag. $20 \mathrm{De}$ invloed van de financiering.

m a b blz. 12 
De behandeling van het valutavraagstuk in de administratieve berichtgeving vereist dat wij in eerste instantie nader ingaan op het huidige internationale geldstelsel. Vervolgens zullen wij trachten een gedragslijn te formuleren met betrekking tot de bepaling van valutakoersen voor de administratieve praktijk.

Tenslotte wordt nader ingegaan op enige administratieve problemen verbonden met de omrekening van vreemde valuta in de valuta van de moedermaatschappij.

\section{Het huidige internationale geldstelsel}

De grondslagen voor het huidige internationale geldstelsel zijn gelegd op de conferentie van Bretton Woods in 1944. De monetaire deskundigen - die deelnamen aan deze conferentie - waren zowel tegen een systeem van volledig vaste wisselkoersen als tegen een systeem van volledig vrije wisselkoersen.

Besloten werd tot het zogenaamde ,adjustable-peg system”. Bij dit systeem zijn de wisselkoersen in beginsel vast, d.w.z. fluctuerend tussen nauw bepaalde gren$\left.z^{2}{ }^{10}\right)$. In geval bij deze vastgestelde koersen de grondslagen voor een duurzaam evenwicht op de betalingsbalans ontbreken, bestaat de mogelijkheid voor een land om met toestemming van het Internationale Monetaire Fonds te revalueren, resp. te devalueren.

Men beschouwde indertijd het ,adjustable-peg system" als een optimaal compromis tussen de voor- en nadelen van vaste en vrije koersen. In de praktijk is het systeem in economisch hoger ontwikkelde landen een stelsel van zo goed als vaste wisselkoersen gebleken. De bereidheid tot wijziging van de wisselkoersen in deze landen is minimaal geweest, o.a. door de vrees dat verandering zou leiden tot evenwichtsverstorende kapitaalbewegingen.

Vele monetaire experts ${ }^{11}$ ) zijn van mening dat er een grotere fluctuatieruimte moet komen voor de wisselkoersen daar onder het huidige stelsel betalingsbalansonevenwichtigheden veelal een structureel karakter hebben gekregen, of structureel dreigen te worden.

Dr. Holtrop - oud-president van de Nederlandse Bank - heeft in een bijzonder knap betoog ${ }^{2}$ ) twee grondoorzaken voor het ontstaan van onevenwichtigheden in het internationale betalingsverkeer onderscheiden:

1 De vraaginflatie, veroorzaakt door een binnenlands overbestedingsproces, of omgekeerd een deflatie door een tekort aan bestedingen.

Dr. Holtrop verklaart dat de vraaginflatie, die altijd samengaat met een te sterk verhoogde kredietexpansie, - het zij ten gunste van het particuliere bedrijfsleven of van de overheid - in het algemeen leidt tot een overspanning van de economie, welke wordt begeleid door een betalingsbalanstekort.

10) Hierop bestaan een aantal uitzonderingen, vooral in het internationale kapitaalverkeer, maar ook in het lopende verkeer van bijvoorbeeld ontwikkelingslanden. De betreffende transacties worden in die gevallen veelal afgewikkeld via afzonderlijke deviezenmarkten met een vrije prijsvorming waardoor de koersen sterkere fluctuaties kunnen vertonen.

11) Men zie the United States balance of payments, 88th Congress, 2nd Session, Senate Report no. 965 van de Joint Economic Commitree. Hierin wordt o.a, aanbevolen dat de Verenigde Staten samen met andere landen meer aandacht schenken aan de gedachte: "to broadening the limit of permissable exchange-rate variation".

12) Een voordracht gehouden op 29 november 1965 voor het Wirtschaftsforum Hessen in Frankfurt am Main. 
In het algemeen zal door een juiste monetaire en budgettaire economische politiek de binnenlandse overbesteding en het tekort op de betalingsbalans kunnen worden gemitigeerd, resp. geëlimineerd.

2 Belangrijke verschuivingen in de vraag naar goederen, diensten en kapitaal in het internationale verkeer. Aanpassingsmechanismen welke het betalingsbalansevenwicht kunnen herstellen zijn:

a. Verschillen in ontwikkeling van de produktiekosten bij de diverse landen. De concurrentiepositie van landen met een relatief sterke stijging van de produktiekosten verslechtert, de concurrentiepositie van landen met een relatief geringe prijsstijging verbetert.

b. Verschillen in ontwikkeling van de rentevoet.

Een land met een relatief hoge rentevoet en een betalingsbalanstekort zal kapitaal aantrekken uit landen met een relatief lage rentevoet en een betalingsbalansoverschot; aldus kan een evenwichtsherstellend kapitaalverkeer ontstaan. c. Toepassing van beperkende maatregelen in het vlak van de internationale handel en het nationale en internationale kapitaalverkeer.

Eenzijdige, zonder voorafgaand overleg getroffen restrictieve maatregelen zijn in deze tijd weinig populair. De reacties op de verhoging van de invoerrechten door het Verenigd Koninkrijk zijn hiervan een sprekend voorbeeld.

d. Wijziging van wisselkoersen.

Dr. Holtrop wijst erop dat de verschillende evenwichtsherstellende mechanismen in een situatie van door vraagverschuiving ontstane tekorten en overschotten in het internationale verkeer sleches gebrekkig werken.

Met name de kosteninflatie in landen mer structurele overschotten in het lopende verkeer werkt in het algemeen slechts langzaam door in de exportprijzen. Dit is te verklaren door de omstandigheid dat in de exportindustrieën veelal arbeidsproduktiviteitsverbeteringen worden gerealiseerd die verre uitgaan boven de gemiddelde produktiviteitsverbetering, waardoor de kostprijsverhogingen in deze sektoren het geringst zijn.

In de economisch hoogontwikkelde landen hebben zich slechts geringe pariteitsveranderingen voorgedaan. Dit is niet verwonderlijk indien men in aanmerking neemt dat een unilaterale pariteitswijziging van een belangrijke valuta - in het bijzonder sleutelvaluta's - zeer grote internationale monetaire en economische consequenties heeft.

Bovendien heeft een sleutelvalutaland geen eigen vrije keuze om een pariteitswijziging effectief te maken; het moet immers niet uitgesloten worden geacht dat de buitenwereld zal volgen. Pariteitsveranderingen blijven dan ook een bij hoge uitzondering en alleen bij zeer duidelijke indicaties toegepast middel van aanpassing $\left.{ }^{13}\right)$.

Een geheel ander beeld zien wij in de ontwikkelingslanden. In de opbouwfase kampen deze landen met een structurele onevenwichtigheid in hun ,basic balance"14). Zij bedienen zich van restrictieve middelen met betrekking tot het goederen-, diensten- en kapitaalverkeer alsmede van fluctuerende en/of multipele koersen.

13) Dr. M. W. Holtrop.

14) De „basic balance" heeft betrekking op de lopende rekening en het structurele kapitaalverkeer. 
Aangezien zij slechts in beperkte mate hun binnenlands overbestedingsproces vanwege sociale repercussies kunnen beteugelen en àndere aanpassingsmechanismen dan koerswijziging onvoldoende werken, staat hun wisselkoers voortdurend onder druk. In deze landen wijzigen de pariteiten dan ook frequent in neerwaartse richting.

\section{Aanbevelingen met betrekking tot het gebruik van valutakoersen in de admini- stratieve berichtgeving}

Het vraagstuk waarmee wij ons vervolgens gaan bezighouden, is: welke koers moet worden gehanteerd bij de omrekening van vreemde valuta in de valuta van de moedermaatschappiij?

Een aan de omrekeningskoers te stellen eis is, dat de daaruit voortvloeiende financiële voorstelling van activiteiten, resultaten en balansposities bedrijfseconomisch juist is. Dit impliceert dat wanneer er sprake is van een fundamentele onevenwichtigheid van de betalingsbalans, en tegen deze achtergrond de officiële koers is overgewaardeerd, deze koers niet mag worden gebruikt voor de balanswaardering.

Overigens dient te worden opgemerkt dat de mate van onevenwichtigheid niet precies kan worden vastgesteld, aangezien de parameters van macro-economische evenwichtsmechanismen niet bekend zijn.

In het voorgaande hebben wij opgemerkt dat in het kader van het huidige internationale geldstelsel de wisselkoersen van de economisch hoog-ontwikkelde landen weinig fluctuaties vertonen. Wij brengen in herinnering dat Dr. Holtrop heeft verklaard dat in het huidige monetaire stelsel pariteitswijziging een slechts bij uitzondering en alleen bij zeer duidelijke indicaties toegepast middel is om het monetaire evenwicht te herstellen. Het is begrijpelijk en ook op bedrijfseconomische gronden juist dat daarom door internationale ondernemingen veelal officiële wisselkoersen worden gebruikt voor de omrekening van het vermogen en de resultaten van buitenlandse deelnemingen in hoogontwikkelde landen.

Wanneer de financiële deskundigen tot de conclusie mochten komen dat voor een evenwichtige groei van de wereldeconomie een grotere fluctuatieruimte (bandbreedte) in de officiële wisselkoersen is geboden, dan blijft, dunkt ons, voorgaande stelling met betrekking tot de hoog-ontwikkelde landen gelden, zij het dat het dan aanbeveling zou verdienen de middenkoers (dit is het midden van het maximum en het minimum van de pariteit) voor de administratieve doeleinden te hanteren.

$\mathrm{Na}$ de oorlog heeft zich de mening verbreid dat het noodzakelijk is om voor ontwikkelingslanden, waarvan de officiële koers is overgewaardeerd, deze offciële koers voor omrekeningsdoeleinden te corrigeren. Zo wordt bijvoorbeeld door het "American Institute of Certificd Public Accountants" aanbevolen om de officiële koers te corrigeren wanneer zich ,significant changes in the value of country's currency" voordoen ${ }^{15}$ ).

In het algemeen was men de mening toegedaan dat men met behulp van de theorie van de koopkrachtpariteit - vooral gepousseerd door de Zweedse economist Cassel - het antwoord kon vinden op de vraag welke koers in deze gevallen zal moeten worden gebruikt. Uitgaande van de these dat betalingsbalansproblemen ontstaan door divergenties in de ontwikkeling van de prijzen van goederen en

15) Chapter 12, Accounting Research and Terminology Bulletins. 
diensten in de diverse landen, wordt volgens de theorie van de koopkrachtpariteit de hoogte van de wisselkoers van de valuta's van 2 landen bepaald door de verhouding tussen de koopkracht van deze valuta's, ergo de reciproke van de prijsniveau's in de betrokken landen.

Vanuit de theoretische gezichtshoek vertoont deze theorie enige gebreken:

- Geen aandacht wordt geschonken aan de invloed van de kapitaal- en kapitaalopbrengstenbalans op de wisselkoers.

- De economische betrekkingen tussen 2 landen worden niet uitsluitend beïnvloed door de ontwikkelingen in die landen zelf, maar ondergaan ook de invloed van de economische ontwikkelingen in andere landen.

- De wisselkoers staat voornamelijk onder invloed van de prijzen van goederen die aan het internationale verkeer deelnemen.

Ook vanuit de praktische gezichtshoek blijkt de theorie van de koopkrachtpariteit gebreken te vertonen.

Blijkens een overzicht van het IFO - Institut für Wirtschaftsforschung ${ }^{16}$ ) - in München over de ontwikkeling van de prijzen (gemeten met behulp van de index van de kosten van levensonderhoud en nog eens apart gemeten met de index van de groothandelsprijzen) en de goud- en deviezenreserves in 28 landen in de periode $1958 / 64$ leidt een hoge geldontwaarding niet noodzakelijk tot een daling van de goud- en deviezenreserve, eerder zou men uit de cijfers een omgekeerde tendentie destilleren.

$\mathrm{Na}$ de oorlog hebben de Verenigde Staten van Amerika, een land met een zeer matige inflatie, de goud- en deviezenreserves het sterkst zien afnemen. Landen met een sterke inflatie zoals Frankrijk en Italië incasseerden grote deviezenstijgingen.

Het is duidelijk dat andere dan prijsfaktoren de betalingsbalans mede beslissend beïnvloeden zoals de technologische ontwikkeling van de exportindustrieën, de ontdekking en exploitatie van natuurlijke rijkdommen, kapitaalbewegingen, hulpverlening, touristenverkeer, transfers van buitenlandse werkkrachten, etc. Wij menen dan ook te mogen concluderen dat koopkrachtkoersen voor omrekeningsdoeleinden niet universeel bruikbaar zijn, doch dat men voor de beoordeling van de betalingsbalans en de wisselkuersen alle factoren - waarvan de belangrijkste hierboven zijn genoemd - mede in beschouwing moeten nemen.

Onderschrijvend dat het voor een juiste balanswaardering vanwege het mitigeren van schokken in de resultatenrekening wenselijk is om voor omrekeningsdoeleinden geen gebruik te maken van geflatteerde officiële koersen, lijkt het ons een verantwoorde gedragslijn in deze gevallen, veelal ontwikkelingslanden betreffende, zogenaamde evenwichtskoersen te hanteren.

Een evenwichtskoers is een koers die op langere termijn leidt tot een structureel evenwichtige betalingsbalans. Het feit dat deze evenwichtige betalingsbalans eventueel behouden blijft door steun van bijvoorbeeld Internationaal Monetair Fonds is ons inziens geen reden de evenwichtskoers als zodanig af te wijzen.

Met inachtneming van alle determinanten van de wisselkoers - zowel de economische als de sociale en politieke - zal door financieel-economische deskundigen een schatting worden gemaakt van de wisselkoers welke zij in de nabije toekomst verwachten.

16) Die Geldwert Illusion, IFO - Schnelldienst, 181 Jahrgang 1965, nr. 37.

$\mathrm{m} \mathrm{a} \mathrm{b}$ blz. 16 
Wij spreken met opzet over nabije toekomst - en denken daarbij aan een horizon van 1 à 2 jaar - omdat het ons weinig zinvol lijkt voorspellingen trachten te doen over een nog langere termijn.

Het verdient aanbeveling om bij deze schatting van de toekomstige koersontwikkeling mede gebruik te maken van de deskundigheid van banken.

Acht men de wisselkoers van een land geflatteerd en verwacht men op basis van een economische analyse in de nabije toekomst een vergroting van de pariteitsoverwaardering met de mogelijkheid van devaluatie over één jaar, dan zou het gebruik van déze toekomstige koers voor de balanswaardering op dít moment minder gewenst zijn.

Voor een benadering van de actuele evenwichtskoers zou men in dergelijke gevallen steun kunnen vinden in de koers welke men verkrijgt door interpolatie van de officiële koers na de laatste devaluatie en de vermoedelijke officiële koers na de eerstvolgende devaluatie. Deze aanpak lijkt ons realistisch met betrekking tot de valuta's van landen welke als gevolg van een structurele overwaardering voortdurend worden gedevalueerd. Voor valuta's waarvan de pariteiten op een tijdstip ver in het verleden het laatst gewijzigd zijn, is de interpolatietechniek ongeschikt en achten wij de in de nabije toekomst te verwachten koers de meest gewenste omrekeningsfactor aangezien deze beschouwd kan worden als een - weliswaar op schattingen gefundeerde - zo objectief mogelijke koers.

Wanneer er sprake is van een meervoudig koerssysteem dient men een gewogen gemiddelde van de desbetreffende koersen te hanteren. Voor de weging zou men het handelspakket van de landseconomie kunnen gebruiken. Deze gedragslijn is preferabel boven een weging met gewichten ontleend aan het verkeer tussen moeder- en dochtermaatschappij.

Immers de officiële koersen zijn een functie van het totale geldverkeer, terwijl het verkeer tussen de moeder- en de dochtermaatschappij slechts een kleine fractie uitmaakt van het totale landsverkeer, met bovendien een te geringe spreiding in de pakketsamenstelling.

Het voorgaande samenvattend wordt voor de hoog-ontwikkelde landen in het algemeen de officiële koers gebruikt, terwijl men voor de ontwikkelingslanden voorzover de valuta's geflatteerd zijn, de zogenaamde evenwichtskoers hanteert. In gevallen van een meervoudig koerssysteem wordt een gewogen gemiddelde bepaald.

In die gevallen, waarbij voor de omrekening officiële koersen kunnen worden gebruikt treden bij de administratieve verwerking geen bijzondere vraagstukken op.

Waar evenwichtskoersen moeten worden toegepast leiden wijzigingen in de omrekeningsfactor tot vermogensveranderingen zonder dat van een reële wijziging van het kapitaalbestand in het betrokken land sprake is. De vraag rijst, hoe deze vermogenswijzigingen - veelal aantastingen van het vermogen - moeten worden behandeld.

In hoofdstuk II hebben wij er reeds op gewezen, dat de gevolgen van prijswijzigingen door toepassing van de vervangingswaarde ten gunste of ten laste van de herwaarderingsrekening worden gebracht.

Gegeven de geformuleerde uitgangspunten voor de bepaling van waarde en winst zou een wijziging van de evenwichtskoers beschouwd kunnen worden als een prijswijziging. De financiële gevolgen hiervan zouden dan niet leiden tot een 
resultaat maar tot een mutatie in het eigen vermogen welke ten gunste of ten laste van de herwaardering moet worden gebracht.

Afgezien van de mogelijkheid door handhaving van het waarde-evenwicht in de balans een nadeel in nominale activa te compenseren met een voordeel in nominale schulden (hetwelk nauw samenhangt met de valutaire samenstelling van nominale middelen en schulden), zal men bij een eventuele netto positie nominale middelen een daaruit voortvloeiend verlies dienen aan te vullen in overeenstemming met de omvang van de activiteiten. De mate waarin het ,trading on the equity" als gevolg van de koersherziening zal wijzigen is bepalend of additioneel eigen dan wel vreemd vermogen zal worden aangetrokken.

\section{DE AANSLUITING VAN DE INFORMATIE OP DE ORGANISATIE}

Zoals reeds in de inleiding werd gesteld is in een grote onderneming - zeker als er sprake is van een brede artikelrange en een sterke internationale spreiding - de gedecentraliseerde organisatiestructuur essentieel. De administratieve informatie zal in een dergelijke situatie de topleiding moeten tonen wat de bijdrage van landsorganisaties en produktgroepen aan de aktiviteit en rentabiliteit van de totale onderneming is. Men zou hier kunnen spreken van ,phenomena reporting", omdat het een integrale rapportering betreft van gezamenlijke acties van lands- en produktgroeporganisaties. Daarnaast zal de informatie moeten aansluiten bij de gedelegeerde verantwoordelijkheden en dan moeten weergeven de resultaten in relatie tot het geïnvesteerde vermogen per bedrijfsonderdeel. Deze informatie zou kunnen worden aangeduid als , responsibility reporting”.

In het geval van een landsorganisatie die volledig autarkisch is - d.w.z. geen produkten behoeft te betrekken van andere buitenlandse organisaties - kan op eenvoudige wijze de rentabiliteit worden bepaald, die door de directie van dat land is gerealiseerd. Hiertoe zullen immers slechts de lokale resultaten in directe relatie tot de lokale investeringen behoeven te worden gebracht. In deze situatie is "phenomena reporting" identiek aan , responsibility reporting”.

In het bijzonder de ontwikkelingen binnen de E.E.G. en E.F.T.A. - maar ook de na-oorlogse liberalisatie van het internationale handels- en betalingsverkeer in het algemeen - hebben tot gevolg gehad dat de internationale concerns een internationale arbeidsverdeling tot stand hebben gebracht. Dit heeft geleid tot een niet onaanzienlijk handelsverkeer tusssen de landsorganisaties van de internationale ondernemingen.

Het uitgangspunt van de ,phenomena reporting” is, dat vanuit het standpunt van de totale onderneming de verkopen en de daarmede verbonden resultaten eerst zijn gerealiseerd op het moment van levering aan derden. De onderlinge leveranties tussen de verschillende landsorganisaties zullen vaak wegens financiële en fiscale redenen met winst moeten worden gefaktureerd. Voor een juiste berichtgeving over de rentabiliteit op integrale basis in een bepaald gebied (land of produktgroep) zullen de resultaten op onderlinge leveranties en het daarmede verbonden kapitaalbeslag moeten worden toegerekend aan die schakel in het bedrijfsproces die uiteindelijk aan derden verkoopt. Wij willen op de methode van eliminatie van deze en andere intercompany-verhoudingen hier niet nader ingaan, maar nu aandacht besteden aan een fundamenteler probleem. 
Door deze berichtgeving op integrale basis is de aansluiting met de organisatie zoekgeraakt. De leider van een onderdeel wordt hier immers ook geconfronteerd met resultaten, die niet het gevolg zijn van zijn handelen en met een kapitaalbeslag dat gedeeltelijk in andere landen of produktgroepen is gelokaliseerd. Ten gevolge van de intercompany-verhoudingen zijn ,phenomena reporting” en "responsibility reporting" niet meer identiek.

Het spreekt vanzelf dat ,responsibility reporting” van primair belang is aangezien de informatie zal moeten leiden tot actie: lovend of lakend, stimulerend, raadgevend.

\section{Responsibility reporting}

$\mathrm{Na}$ de oorlog heeft de mening postgevat dat budgetcontrole alléén niet meer toereikend is om in een grote geïntegreerde onderneming de spirit van het ondernemerschap in de gelederen van de leiding te bewaren.

Als gevolg hiervan is de profit-centre gedachte ontstaan. „Great racers like to test their abilities against the clock. Likewise great entrepreneurs want to compete with profit as the yardstick. People with great need for achievement want to work where knowledge of results is direct, immediate and concrete"17). De profitcentre gedachte maakt het mogelijk de rentabiliteit als criterium voor beleidsbepaling en beleidsbeoordeling in alle organisatorische eenheden van de onderneming op directe wijze te doen functioneren. Inhaerent aan het profit-centre systeem is uiteraard dat intercompany-leveringen niet tegen kostprijs worden gefaktureerd. Het probleem is dan wèlke transferprijzen dienen te worden gehanteerd. Men heeft de keuze uit de volgende prijzen:

1 marktprijzen,

2 prijzen welke tot stand komen uit onderhandelingen tussen interne leverancier en interne afnemer,

3 prijzen welke worden voorgeschreven door de topleiding, respectievelijk een neutrale commissie in de ondernemingscentrale,

4 prijzen welke de resultante zijn van de normatieve kostprijs van de interne leverancier plus een redelijke beloning voor het kapitaalbeslag van de interne leverancier (fair return on capital).

Wij zullen achtereenvolgens deze mogelijkheden nader in beschouwing nemen.

\section{Marktprïzen}

Verrekening op basis van marktprijzen zou voor een objectieve beoordeling van de prestaties van de onderdelen van een onderneming uiteraard de meest ideale oplossing zijn.

Ten gevolge van produktdifferentiatie zijn er echter veelal voor halffabrikaten en onderdelen geen marktprijzen voorhanden. Indien in bepaalde gevallen wel marktprijzen ter beschikking staan, past toch nog de nodige voorzichtigheid. Men dient zich er namelijk rekenschap van te geven dat de prijszetting behoort te geschieden op basis van een long term prijsniveau, omdat kortstondige fluctuaties, veroorzaakt door de vraag- en aanbodsverhoudingen een misleidend idee geven over de winstpotentie van deze artikelen.

17) W. J. Butler \& J. Dearden, Harvard Business Review 43 (1965) nr. 3. 


\section{Onderhandelingsprijzen}

Aan dit onderwerp is door onderzoekers reeds aandacht besteed in de literatuur.

Mc. Lain veroordeelt het systeem van onderhandelingsprijzen: „Price negotiation between divisions diverts managerial efforts from more important matters and leads to unpredictable results"'18).

Ook Dearden onderkent de gevaren verbonden aan het systeem van onderhandelen. „One of the most annoying problems associated with many interdivisional pricing systems is the acrimonious debate and the resulting ill feelings which so frequently accompany price negotiations". ${ }^{19}$ ) Over de euvelen van „,chronic quarreling” merkt deze onderzoeker op: „I know of no completely satisfactory answer to this problem. One of the most important considerations is the choice of people to conduct the negotiations".

Dat ook het bedrijfsleven zwaar tilt aan de moeilijkheden verbonden aan de vaststelling van onderhandelingsprijzen, moge blijken uit een onderzoek van Stone dat betrekking had op de praktijk van 505 bedrijven.

„both market and cost-based prices are widely used but negotiated prices are inf requently used and only in a supplemental way"20).

Naar onze mening is toepassing van onderhandelingsprijzen in een grote geintegreerde onderneming niet wenselijk, omdat de aandacht van de leiding op alle niveau's relatief te veel wordt gericht op , internal paper affairs" en te weinig op „external real affairs”. Dit klemt des te meer indien men aan de conceptie van profit-centres niet will koppelen het aspect van de volledige operationele onafhankelijkheid, d.w.z. de vrije toegang tot in- en verkoopmarkt.

\section{Voorgeschreven prïzen}

Het syteem van door het topmanagement of door een centrale commissie voorgeschreven prijzen - waarbij men bij de bepaling van de prijzen rekening te houden heeft met een redelijke winst voor de leverancier en bovendien voldoende ruimte moet laten aan de afnemer om ook een redelijke winst te maken - achten wij in het algemeen minder geschikt. Het is n.l. bijzonder moeilijk en wellicht haast onmogelijk om vanuit de centrale van een sterk geïntegreerde onderneming - naast een beoordeling van de diverse nationale commerciële mogelijkheden - gelijktijdig er zorg voor te dragen dat de elkaar toeleverende bedrijfsonderdelen een redelijke beloning ontvangen.

\section{Kostprïs plus "fair return on capital"}

$\mathrm{Bij}$ dit systeem wordt de kostprijs van de interne leverancier inclusief bijkomende kosten, verhoogd met een redelijke vergoeding voor het kapitaalgebruik. Deze vergoeding willen wij baseren op een in de long run voor de onderneming wenselijk geachte minimale rentabiliteit. Bij de bepaling van deze rentabiliteit dient rekening te worden gehouden met:

- vergoedingen aan verschaffers van eigen en vreemd vermogen

- winstuitkeringen aan personeel

18) R. Mc Lain, Transfer Pricing contribute to divisional performance evaluation, NAA bulletin aug. "63.

19) J. Dearden, Interdivisional Pricing, Harvard Business Review, vol. 38 (1960) nr. 1.

$\left.{ }^{20}\right)$ W. E. Stone, Management Practices with Respect to Internal Transfer Pricing in Large Manufacturing Companies, Accounting Review, Oct. 1959. 
- wensen met betrekking tot de interne financiering, d.i. financiering uit de winst

- de aanspraken van de fiscus op de winst.

Alle 4 behandelde systemen bieden (althans in principe) de mogelijkheid de filosofie van ,the manager is a profitmaker" tot een realiteit te maken.

Onze keuze valt - op grond van de volgende praktische voordelen - op het $4 \mathrm{e}$ systeem:

- elke interne afnemer wordt geconfronteerd met een prijs waarin door alle (voorgaande) leveranciers is gerekend met een kapitaalvergoeding. Zonder de zekerheid te hebben dat de rentabiliteit van de totale onderneming toeneemt, bereikt men in ieder geval dat de leiders op alle niveau's meer rentabiliteitsbewust zijn;

- de in principe uniforme kapitaalvergoeding maakt het in het algemeen mogelijk met één kengetal de winstgevendheid van alle toeleverende bedrijfsonderdelen te vergelijken.

Uitzonderingen op het beschreven systeem dienen te worden toegelaten waar de markt dat apert dicteert. Ook is in een dergelijke regeling plaats voor variabele overdrachtsprijzen afhankelijk van seriegrootte en levertermijn. De noodzakelijke samenspraak hierover tussen technische en commerciële sector zullen de totale rentabiliteit van de onderneming ten goede komen.

\section{Prospectieve informatie}

Wij zijn er voorstander van dat gedecentraliseerde onderdelen over een zo groot mogelijke mate van zelfstandigheid beschikken. Teneinde echter een evenwichtige en doelgerichte ontwikkeling van de onderneming als geheel zeker te stellen zal het beleid van de onderdelen cohaerent zijn aan het beleid van de topleiding. Ook zal het beleid in de bedrijfsonderdelen moeten worden gecoördineerd.

Voor de formulering van haar beleid en de onderlinge afstemming van activiteiten, behoeften en mogelijkheden zal de topleiding van de onderneming ondersteuning vinden in een regelmatige informatie vanuit de concernonderdelen betreffende de door deze verwachte, resp. gewenste ontwikkeling en de wijze waarop deze moet worden gerealiseerd. Het hulpmiddel voor deze beleidsafstemming is het huishoudplan op middellange en korte termijn. Het huishoudplan kan worden gekarakteriseerd als een ,aide de communication" tussen de verschillende niveau's van leiding ten behoeve van de vaststelling van het toekomstige beleid.

Daarbij willen wij er de aandacht op vestigen dat het eenmaal ingediende plan een statische momentopname is, omdat het een weergave is van de situatie en de inzichten zoals die golden op het moment van het opstellen der plannen. Aangezien de "facts of life" voortdurend wijzigen zou het te lang vasthouden aan een bepaald plan van onvoldoende werkelijkheidszin getuigen, c.q. tot foutieve beoordelingen en beslissingen t.a.v. gebeurtenissen en siutaties leiden. In de planningprocedure zullen derhalve zodanige maatregelen worden ingebouwd, die de mogelijkheid bieden de zich wijzigende inzichten van topleiding en lagere niveau's van leiding tot uiting te brengen in van het oorspronkelijke plan afwijkende besturingsimpulsen.

Via deze „feed back and feed forward" procedure zal de prognose voor een bepaalde periode steeds verdergaand geconcretiseerd en gepreciseerd worden. Wanneer we in aanmerking nemen dat het realiteitsgehalte van een plan toeneemt 
naarmate de planperiode korter wordt, kunnen we het budget (1-jaar plan) beschouwen als de definitieve beslissing terzake van het in de onmiddellijke toekomst te volgen beleid. Daarmede is het budget als beleidsplan een middel tot beleidsoverdracht en daardoor tevens taakopdracht en machtiging. Voorts is het een belangrijke repressief instrument voor de leiding bij de verificatie van het gevoerde beleid en de uitvoering.

Plannen op middellange termijn - welke naar hun aard niet anders dan globaal kunnen zijn - pogen een oriëntatie te verschaffen omtrent de voorgenomen policy en de daaraan verbonden konsekwenties.

Het budget daarentegen is normaticf en concretiseert in detail de geplande uitvoering van de policy op korte termijn. Hierdoor kan het als maatstaf voor de beoordeling van het werkelijke bedrijfsgebeuren fungeren en derhalve dient de retrospectieve informatie te worden geconfronteerd met het budget.

\section{De invloed van de financiering}

In een internationale onderneming heeft de financiering in het algemeen centrale accenten.

Een centrale vaststelling van het financieringsbeleid ligt in de rede, aangezien de internationale onderneming veelal als eenheid naar buiten optreedt en door de vermogensverschaffers ook als zodanig wordt beoordeeld. Belangrijke kostenbesparingen worden verkregen indien centraal in de vermogensbehoeften van alle bedrijfsonderdelen wordt voorzien. Gedacht wordt met name aan de voordelen van schaalvergroting en de invloed van het diversiteitsverschijnsel.

Het is daarom logisch dat centraal bijvoorbeeld vorm, omvang en tijdstip van emissies worden bepaald en de keuze van verschillende vormen van vreemd vermogen in grote lijnen wordt vastgelegd. De conceptie van een centraal geleide financiering impliceert, dat onderling wellicht sterk verschillende financiële structuren der bedrijfsonderdelen geen zelfstandige betekenis hebben bij de beleidsbepaling en de beleidsbeoordeling van de bedrijfsonderdelen met behulp van het rentabiliteitscriterium. In dit geval zal de invloed van de financiële structuur moeten worden geëlimineerd.

In het kader van ,responsibility accounting” zou een konsekwentie van deze gedachtengang kunnen zijn, dat de in de bedrijfsonderdelen aan derden betaalde rente moet worden ,gepooled" en niet meer moet worden verbijzonderd naar de bedrijfsonderdelen. Daar echter de condities waartegen plaatselijk wordt geleend, dikwijls in belangrijke mate door de lokale leiding worden beïnvloed en bovendien de rente veelal een belangrijke kostenpost vormt, is het gewenst de invloed van de wijze van financiering in voor- en nacalculatie afzonderlijk te tonen.

Aangezien voor de optimalisering van het totale ondernemingsbelang de bepaling van het financiële beleid in nauw overleg tussen de ondernemingscentrale en de bedrijfsonderdelen zal plaatsvinden, zullen de financiële gestes van de leiding van de bedrijfsonderdelen niet anders kunnen worden getoetst dan tegen de achtergrond van het uit het overleg voortvloeiende plan, resp. de daarin geformuleerde taakstelling (,performance measurement”).

\section{De betekenis van economische blokvorming}

In het voorgaande is reeds gewezen op de invloed die de na-oorlogse economische blokvorming - E.E.G., E.F.T.A., L.A.F.T.A. - heeft voor een steeds verdergaande 
internationale arbeidsverdeling. De nog steeds bestaande handelsbarrières tussen de blokken leiden er echter toe, dat deze arbeidsverdeling zich voorshands voornamelijk binnen de blokken manifesteert. De met deze arbeidsverdeling gepaardgaande productspecialisatie leidt tot het ontstaan van z.g. ,supply-centres", dat zijn fabrieken die niet meer alleen produceren voor de lokale markt, maar zijn gericht op de dekking van de behoeften van de verkooporganisaties binnen een economisch blok.

De onderlinge verwevenheid en afhankelijkheid van de onderscheiden landsorganisaties neemt hierdoor in zo'n belangrijke mate toe dat een sterkere centrale coördinatie is vereist ${ }^{21}$ ). Deze centralisatie is primair gericht op het artikelbeleid. $\mathrm{Zij}$ manifesteert zich in eerste instantie in de fabricagesector, waarbij wij met name denken aan de planning, maar zal zich bij de sterkere eenwording van de landseconomieën ook gaan uitstrekken tot de commerciële aktiviteiten van de onderneming. Eenwording van markten heeft in het commerciële vlak tot gevolg dat verkoopprijzen, leveringscondities, kwaliteitseisen, etc. niet meer autonoom per deelmarkt kunnen worden vastgesteld.

Indien wij ons afvragen, wat deze organisatorische ontwikkelingen betekenen voor de administratieve informatie, dan valt vooral de verschuiving op die wordt teweeg gebracht in het traditionele patroon van taken, bevoegdheden en verantwoordelijkheden. Was voorheen zowel de beleidsvorming als de beleidsuitvoering in belangrijke mate landsgericht, de nieuwe ontwikkelingen resulteren in een sterkere coördinatie van het artikelbeleid gericht op grotere geografische gebieden.

De informatie voor de oordeelsvorming ex-ante zal daarom naar de ondernemingscentrale worden geleid in een zodanige vorm dat zij aan dit coördinerend artikelbeleid kan worden dienstbaar gemaakt.

\section{De kosten van centraal beheer}

De organisatie van de internationale onderneming brengt met zich mee dat bepaalde taken ten behoeve van de onderneming als geheel worden verricht. Wij denken hierbij aan de algemene leiding en de centrale staforganen, de centraal verrichte fundamentele research, en de centrale produktgroepenorganisaties.

De kosten die aan deze activiteiten verbonden zijn behoren ten laste van de landsorganisaties te worden gebracht. Verrekening is om financiële en fiscale redenen niet altijd mogelijk. Er zal gestreefd moeten worden naar fakturering van diensten, die rechtstreeks ten behoeve van bepaalde organisaties worden verricht, bijvoorbeeld technische hulp. Het is veelal mogelijk met de landsorganisaties dienstverleningscontracten af te sluiten, waarin bepaalde vergoedingen worden overeengekomen voor het gebruik van de in de centrale aanwezige kennis op technisch, commerciëel en administratief gebied, welke ook fiscaal worden erkend.

In een aantal gevallen is op deze wijze toch slechts een gedeeltelijke vergoeding van de centraal gemaakte kosten mogelijk.

Hoewel we ons realiseren dat hierdoor bepaalde problemen in het vlak van de financiering ontstaan, gaan we hier aan voorbij om ons te concentreren op enige

21) Een interessante beschouwing over het vraagstuk van centralisatie en decentralisatie is gepubliceerd door: Zenon S. Zannetos, „On the theory of divisional structures: Some aspects of centralization and decentralization of control and decision making", Management Science: Vol. 12, (1965), No. 4. 
vraagstukken van kosten en kostprijs. De in de dienstverleningscontracten opgenomen vergoedingen zijn veelal voor de kostprijsberekening niet relevant omdat men er slechts zelden in slaagt, de bedrijfseconomisch juiste bedragen te contracteren. Het is voor een juiste kostprijsberekening van groot belang dat daarin de volledige bedragen van het centraal beheer worden opgenomen. Wij realiseren ons, dat verbijzondering van deze kosten bepaalde weerstanden kan oproepen welke vooral veroorzaakt worden door het feit, dat de landsorganisaties deze kosten niet kunnen beïnvloeden en er ook geen verantwoordelijkheid voor dragen. Uit een oogpunt van ,responsibility reporting" is toerekening van deze kosten aan de landsorganisaties derhalve minder gewenst. Daartegenover staat echter dat deze kosten mede ten behoeve van de landsorganisaties worden gemaakt en daardoor ter plaatse tot lagere kosten, of/en tot hogere opbrengsten leiden. Wanneer wij daarenboven in aanmerking nemen dat toerekening van deze kosten bepaalde discussies oproept, welke voor de kostenbewaking zeer nuttig zijn, dan zijn wij van mening, dat het gewenst is, deze kosten aan de bedrijfsonderdelen toe te rekenen. In de rapportering van de landsresultaten moeten dan ook de zo goed mogelijk verbijzonderde kosten van centraal beheer in de plaats worden gesteld van de bedragen voortvloeiend uit de dienstverleningscontracten.

De verbijzondering van deze kosten vereist bijzondere aandacht. In de eerste plaats zal direkte toerekening waar mogelijk te prefereren zijn, bijvoorbeeld hulp vanuit de centrale bij het bouwen en op gang brengen van een nieuwe fabriek.

Daarnaast moet worden gezocht naar verdeelsleutels die zinvol zijn, d.w.z. dat hiermee zo goed mogelijk het causale verband tussen kosten en produkt of produktgroep wordt benaderd. Zo zullen kosten van fundamentele research beter kunnen worden verbijzonderd op basis van de toegevoegde waarde dan van de omzet en zal het bij de verbijzondering van de kosten der centrale produkrgroepen nuttig zijn onderscheid te maken tussen eigen gefabriceerde- en inkoopartikelen.

Tenslotte willen wij er op wijzen dat het topmanagement van een internationale onderneming scherpe aandacht zal moeten besteden aan de budgetten van de afdelingen die wij hebben samengevat onder de term ,centraal beheer”. Deze afdelingen zijn namelijk bijzonder expansief en zoals Butler en Dearden ${ }^{22}$ ) zeggen: „may become professional ends in themselves rather than means to the end of profit".

\section{Consolidatieproblemen}

Het doel van de consolidatie is een juist inzicht te geven in de vermogenspositie op een bepaald moment en het resultaat over een periode van het concern als totaliteit, zodat een duidelijk inzicht wordt gegeven in solvabiliteit, liquiditeit en rentabiliteit, waarbij door de juridische verhoudingen wordt heengezien. Fundamenteel is hier het voldoen aan de eis dat de informatie de bedrijfseconomische realiteit weergeeft, cvenals dit het geval was bij het hiervoor geschetste valutaprobleem. In dit verband zij opgemerkt dat het betitelen van het laatstgenoemde vraagstuk als consolidatievraagstuk onjuist is. Ook indien niet wordt geconsolideerd zal men het valutaprobleem moeten oplossen om tot een juiste informatie over de activiteiten en resultaten van de lands- en produktgroeporganisaties te geraken.

${ }^{22}$ ) W. J. Butler and J. Dearden. Managing a worldwide business, Harvard Business Review, (Boston), 43, (1965), no. 3 .

m a b blz. 24 
De niet geconsolideerde balans en resultatenrekening van de moedermaatschappij geeft geen inzicht in de liquiditeit, solvabiliteit en rentabiliteit van het concern als economische eenheid. Eerst bij consolidatie wordt de post deelnemingen gesplitst in vast en vlottend kapitaal en vreemd vermogen op lange en korte termijn, terwijl het resultaat deelnemingen dan gespecificeerd wordt naar de functionele opbouw.

Een belangrijk vraagstuk is, welke deelnemingen moeten worden geconsolideerd en welke niet. Als uitgangspunt stellen wij dat de geconsolideerde jaarrekening een beeld dient te geven van de economische eenheid, díe door de juridisch gescheiden ondernemingen wordt gevormd. Dan zullen die deelnemingen moeten worden geconsolideerd, waarin de leiding van de moedermaatschappii blijvend een beslissende invloed heeft op het beleid en waarvan de activiteiten in de werkingssfeer van het geheel passen. Een dergelijke beslissende invloed zou behalve door het bezit van een meerderheid van het aandelenkapitaal bijvoorbeeld ook kunnen worden verkregen door houderschap van aandelen met preferenties ten aanzien van bestuursbenoemingen of door contracten.

In dit verband zij opgemerkt dat volgens de Engelse Companies Act 1948 reeds sprake is van een deelneming indien de moedermaatschappij ,,controls the composition of its board of directors or holds more than half the nominal value of its equity share capital". Consolidatie vindt echter niet plaats als, ,it is impracticable or would be of no real value" en "the results would be misleading or harmfull to the business of the company" en "the business of the holding and that of the subsidiary are so different that they cannot reasonably be treated as a single undertaking".

In de Verenigde Staten is men blijkens Accounting Research Bulletin nr. 51 van augustus 1959 van mening dat „,ownership by one company, directly or indirectly, of over fifty percent of the outstanding voting shares of another company is a condition pointing toward consolidation". Voorts wordt in dit bulletin verwezen naar chapter 12 of Accounting Research Bulletin nr. 43 over de behandeling van buitenlandse deelnemingen. Uit dit laatste bulletin blijkt dat men een aparte consolidatie van de buitenlandse deelnemingen noodzakelijk acht, gezien de risico's verbonden aan het werken met andere valuta's. Als bezwaar tegen deze stelling kan worden aangevoerd dat de structuur van een internationale onderneming impliceert dat de waardering van valutarisico's een normaal onderdeel van de beleidsbeslissingen moet vormen. Van deze waarderingsgrondslagen zal dan ook gebruik gemaakt kunnen worden in de berichtgeving; een noodzaak tot een andere vorm van publicatie is dan niet aanwezig.

In Nederland is door een studiecommissie onder voorzitterschap van Prof. Verdam een rapport gepubliceerd in de vorm van een voor-ontwerp van wet waarin als deelneming wordt omschreven ,het houden van aandelen van een onderneming tot een nominale waarde van tenminste een vierde gedeelte van haar geplaatst kapitaal".

Ten aanzien van het vraagstuk van al of niet consolideren wordt gesteld: ,omtrent de ondernemingen waarin door de deelneming rechtstreeks of middellijk zeggenschap bestaat over meer dan de helft van het geplaatst kapitaal worden voorts alle gegevens verstrekt die krachtens deze wet in de jaarrekening moeten voorkomen. Deze gegevens worden verstrekt hetzij in de vorm van afzonderlijke 
of samengevoegde jaarrekeningen van deze ondernemingen, hetzij in die van een geconsolideerde jaarrekening van de onderneming". Met het laatst vermelde begrip „onderneming" wordt de „deelnemende" onderneming bedoeld. ${ }^{23}$ )

In normale gevallen zal geconsolideerd worden op een zodanige wijze dat in het geconsolideerd vermogensoverzicht de aktiva en passiva voor $100 \%$ worden opgenomen en het minderheidsbelang van derden afzonderlijk wordt vermeld, terwijl ten aanzien van het geconsolideerd resultatenoverzicht op analoge wijze wordt gehandeld. Bij de zogenaamde proportionele consolidatie worden de aktiva-, passiva- en de resultatencomponenten van de deelnemingen voor het deelnemingspercentage in de geconsolideerde overzichten opgenomen. Wij zijn van mening dat de techniek van proportioneel consolideren slechts in uitzonderingsgevallen toepassing kan vinden en wel alleen bij 50\% deelnemingen waarin met één andere onderneming wordt samengewerkt en waarin een duurzame 50/50 verhouding wordt beoogd (joint-ventures). Alleen in dit geval is sprake van een gedeelde verantwoordelijkheid voor de gevolgen van het gevoerde beleid.

Werd in het begin van dit onderwerp gesteld dat de informatie de bedrijfseconomische realiteit zal dienen weer te geven, duidelijke eis zal dan zijn, dat naast „uniformiteit" in de bedrijfseconomische conceptie t.a.v. de waarderingsgrondslagen, de administratieve verslaglegging zoals deze door de verschillende concernonderdelen wordt opgesteld ten behoeve van de consolidatie zal dienen te stoelen op een rekeningenstelsel, dat naar opbouw en terminologie aansluit op de geconsolideerde jaarrekening.

\section{De betekenis van bedrijfsvergelijkingen}

De voornaamste doelstelling van de bedrijfsvergelijking is, een stimulans te verkrijgen tot vergroting van de produktiviteit, tot verlaging van de kostprijs en daardoor tot verhoging van de rentabiliteit.

Het is een van de voordelen van de internationale onderneming, dat men voor toetsing van het gebeuren in een bedrijfsonderdeel mede gebruik kan maken van de ervaring in andere gelijksoortige onderdelen binnen de onderneming. Voorts worden in verschillende landen produkten met dezelfde of soortgelijke produktietechnieken vervaardigd. De snelle voortschrijding van de techniek, gecombineerd met de per land bereikte efficiencyverbetering veroorzaakt geleidelijk verschillen in methoden en constructie. Ook is het vanuit het standpunt van de totale onderneming noodzakelijk zich voortdurend te heroriënteren betreffende het al of niet zelf vervaardigen van materialen en onderdelen; terwijl binnen de onderneming de vraag rijst waar bepaalde produkten het best kunnen worden voortgebracht. Als belangrijk hulpmiddel bij de bedrijfsvergelijking is een analyse van de kostprijzen van betekenis.

Een analyse van de kostprijzen alléén bergt echter een gevaar in zich van verkeerde beleidsbeslissingen, het is namelijk voor de onderneming ook onmisbaar een duidelijk inzicht te verkrijgen in de omstandigheden waaronder de te vergelijken bedrijfsonderdelen werken. Naast het financiële en kwaliteitsaspect van de vergelijkingen speelt het $\mathrm{kwantitatieve}$ aspect de belangrijkste rol. De mogelijkheden tot produktvergelijkingen doen zich voor bij:

- identieke of bijna gelijkwaardige produkten welke worden geproduceerd op verschillende plaatsen

23) Blz. 17 S.E.R. advies. 
- verschillende produkten behorende tot dezelfde familie van produkten welke worden geproduceerd op verschillende plaatsen

- produkten welke niets met elkaar gemeen hebben, maar waarbij dezelfde produktietechnieken worden toegepast.

Bij de kostprijsanalyse stuiten we op:

Verschillen in hoeveelbeden

Deze verschillen hebben betrekking op materiaalverbruik, fabricagemethoden en man- en machine-uren. Voor identieke of bijna gelijksoortige produkten kan de zogenaamde "selected method" worden toegepast. Deze methode analyseert manen machinetijden per land tot de kleinst mogelijke elementen.

Door het selecteren van de goedkoopste elementen, nl. die met de laagste uitvalcijfers en hoogste graad van efficiency kan een produktiemethode worden opgebouwd welke vanuit de totale onderneming als ideaal gekarakteriseerd kan worden (selected method). Een detailvergelijking van deze ideale fabricagemethode met de toegepaste in de verschillende landen toont aan waar en hoe de efficiency kan worden verbeterd.

\section{Verschillen in prijzen}

De prijsverschillen betrekking hebbende op materialen geven aanleiding tot een onderzoek naar de vraag of het voordeliger is onderdelen en grondstoffen uit andere concernfabricageplaatsen te betrekken of tot een overzicht aangevende bij welke externe leveranciers deze produkten goedkoper kunnen worden ingekocht (make or buy). Alle prijzen dienen voor deze vergelijking op vervangingswaarde te worden gebracht en op een uniform prijsniveau met eliminatie van intercompany resultaten.

\section{Verschillen in tarieven}

De verschillen in tarieven en tocslagen daarop worden veroorzaakt door:

- variaties in kostenniveau

- verschillen in organisatie

- verschillende gezichtspunten van de leiding ten aanzien van taakstellingen

- verschil in differentiatie in de uurtarieven.

Een doorlichting van de produktie-organisatie en hulpafdelingen ten aanzien van deze aspecten is wezenlijk voor een mogelijke efficiencyverbetering.

In het voorgaande hebben we ons hoofdzakelijk bepaald tot vergelijkingen van identieke of bijna gelijksoortige produkten. Voor produkten die sterk van elkaar verschillen, ofschoon ze tot dezelfde familie van produkten behoren, kunnen vergelijkingen als voren beschreven niet worden toegepast en zullen we ons hierbij dienen te beperken tot onderdelen van het produkt die wel vergelijkbaar zijn, of tot een vergelijking van die produktietechnieken die ze voor een deel wel gemeen hebben. Krijgen we hier dus niet zo'n gedetailleerde informatie als bij gelijke of gelijkvormige produkten, toch krijgen we voor de wèl vergelijkbare delen nuttige informatie voor een mogelijke verbetering van de efficiency.

\section{Indoctrinatie, training en opleiding van administratieve medewerkers}

De wetenschap, dat ,administratie" zich in een snel tempo ontplooit tot een informatiesysteem, waarvan het zwaartepunt zich heeft verlegd van zuiver 
numerieke informatie (het traditionele boekhoudsysteem) naar de interpretatie daarvan en van retrospectieve naar prospectieve informatie, vraagt ook binnen de administratieve organisatie om maatregelen van communicatieve aard. Het zijn nl. ook hier communicatieprocessen (het overbrengen van informatie) om de administratieve medewerkers bepaalde inzichten en verworvenheden in hun vakgebied bij te brengen, of ook wel het overwinnen van weerstanden en het kweken van een bepaalde gezindheid. Hoewel reizen zowel in tijd, als geld kostbaar is, is het persoonlijk contact van essentieel belang in deze communicatie. Alleen hierdoor zal de appreciatie van de wederzijdse taken bij een internationale onderneming, zowel van de centrale administratieve organen als van de „operating units" kunnen worden verbeterd.

Naast deze contacten in engere zin zijn hier ook van betekenis, job rotation" (ook internationaal), indoctrinatiecurssussen voor nieuwe medewerkers en ondersteuning en stimulering bij het volgen van voortgezette externe opleidingen. Ook conferenties, die breder vormen dan in het eigen vakgebied of specialisme, en die een verdieping van kennis en inzicht opleveren, zijn van nut ter vergroting van de doeltreffendheid van de administratie als informatieverwerkend en -verstrekkend apparaat ten behoeve van het besturen en doen functioneren der onderneming.

Gezien vanuit de behoefte aan informatie voor de hoogste leiding van de internationale onderneming, zal men bij de "flow of information" van uit de gedecentraliseerde administratieve units en ten behoeve van de consolidatie dezer gegevens de vereiste uniformiteit in vorm, principe en totstandkoming dezer gegevens dienen te bewaren.

Het middel om deze uniformiteit te handhaven is het centraal opstellen van richtlijnen en instructies. Deze eis tot uniformiteit à tort et travers doorvoeren betekent evenwel een gevaar tot verstarring van het administratieve apparaat, terwijl juist de administratie een „levend" instrument is voor de bedrijfsleiding. Ook hier geldt dat een nauwe samenwerking en overleg tussen de centrale instantie verantwoordelijk voor het opstellen van richtlijnen en instructies en de „operating units" noodzakelijk is voor een doelmatige organisatie van de administratieve arbeid. Richtlijnen en instructies moeten vooral begrepen worden door hen die ze ontvangen en toepassen, omdat ze alleen door juiste interpretatie goed kunnen worden gevolgd in de praktische uitvoering. Ook de groeiende interdependentie van administratieve informatie en informatie verbonden met de uitvoering van werkzaamheden in andere functies benadrukt de onderlinge afhankelijkheid en de noodzaak tot wederzijdse samenwerking. Het werken in teamverband opgeroepen door deze complexiteit van taken en organen in een internationale onderneming vraagt naast de eisen van deskundigheid van de administrateur in zijn vakgebied ook om het aankweken van die karaktereigenschappen, welke nodig zijn om met respectering van elkaars functies een samenwerking in teamverband mogelijk te maken. Bij de dienende taak van de administrateur, daarbij gebruik makende van zijn specifieke kennis gepaard aan bedrijfservaring in de sfeer van de bedrijfseconomische aspecten der besluitvomring, zal deze er zich tevens van bewust moeten zijn dat ook de niet kwantificeerbare, niet bedrijfseconomische elementen een grote betekenis hebben. Rekening houdende met de voorgaande geschetste tendenzen zal het een taak zijn van de administratieve leiding zowel lokaal als centraal haar administratieve medewerkers in deze zin te vormen en te enthousiasmeren en internationaal te leren denken. 


\section{Het begrip automatisering}

Wij zullen ons in hoofdzaak beperken tot de automatisering van de informatieverwerking en -veredeling.

Sedert een 15-tal jaren spelen computers een rol in de informatieverzorging. Soms wordt deze apparatuur alleen gezien als een hulpmiddel ter vervanging van andere informatieverwerkende machines of van menselijke arbeid. Computers hebben echter een eigen inbreng. Illustratief is een vergelijking met een automatische piloot in vliegtuigen. Deze "hardware" is niet primair aangeschaft om de piloot te vervangen, doch dient veeleer om het vliegen efficiënter, betrouwbaarder en comfortabeler te maken. Computers kunnen ook fungeren als een automatische piloot in de onderneming. $\mathrm{Zij}$ dragen bij tot een verbeterde besturing, juist onder snel wisselende omstandigheden.

De massaliteit van gegevens die voor besturing nodig is, het complexe karakter van deze gegevens en de noodzaak tot snelle reactie, nopen tot het gebruik van middelen welke de verzameling en verwerking van gegevens en de terugkoppeling van informatie snel en betrouwbaar verzorgen. Dit geldt a fortiori voor de internationale onderneming. $\mathrm{Zij} z a l$ dan ook voorop moeten gaan bij de toepassing van deze middelen, te weten computers en systemen. De computer biedt mogelijkheden tot integratie van gegevensverwerking en informatieverstrekking welke voordien door een beperktheid van de technische hulpmiddelen ondenkbaar waren. In dit verband citeren wij $\mathrm{Mr}$. Crossman van de universiteit van Californië die onlangs in de O.E.C.D.-conferentie over Man-Power Aspects of Automation and Technical Changes stelde: "The computer was really a breakthrough in science in making it possible to take over many human information processing functions".

\section{Soorten van informatie}

Onder informatie verstaan wij de betekenis-inhoud van geordende gegevens, waardoor het kennisbeeld over bepaalde feiten, toestanden en gebeurtenissen wordt opgebouwd.

In het kader van dit onderwerp is vooral de automatisering voor bestuurlijke processen van belang waaronder wij dan verstaan het door middel van computers verwerken en veredelen van gegevens tot direkt voor besturing bruikbare informatie.

Naar de aard is de informatie als volgt in te delen:

1 Informatie voor formele regelingsbeslissingen, die aan lagere niveau's gedelegeerd, resp. aan de computer overgelaten kunnen worden, omdat zij volledig gedetermineerd zijn.

2 Informatie over uitzonderingen, die buiten de „limits of delegation”, vallen. Ingrijpen door een hoger niveau in de organisatie wordt nodig.

3 Informatie over alternatieve mogelijkheden van beleidsvoering.

4 Informatie over gegevens waarvan de veredeling door bijkomende niet kwantificeerbare imponderabilia zich thans nog niet leent voor programmering. Dit is waarschijnlijk in de toekomst wél mogelijk door toepassing van zgn. heuristische methoden. 


\section{Fasen in de automatisering}

In een primitieve fase van computertoepassing, waarin bepaalde deelwerkingen worden gemechaniseerd zoals bij een loon- of salarisberekening, is van automatisering nog geen sprake. De computer wordt hier uitsluitend als rekentuig gebruikt maar levert geen bijdrage in de besturing van een proces.

Ook integratie van bepaalde deelbewerkingen zoals de registratie van produktie en voorraden met behulp van een computer kan nog niet als automatisering worden bestempeld.

$\mathrm{Bij}$ automatisering denken wij aan gegevensverwerking die is gericht op het produceren van informatie en/of signaleren ten behoeve van de besturing. Bij sommige systemen is het besturingskarakter heel sterk anwezig, bij andere ligt de nadruk meer op het verkrijgen van informatie. Naarmate meer kennis van een proces wordt verkregen en de moeilijkheden tot programmering worden vergroot. verschuift het accent in de gegevensverwerking via de computer, van het verkrijgen van informatie naar het verstrekken van besturingssignalen. Het is evident dat de invloed van deze ontwikkeling op de menselijke besturing, zoals die op vele niveau's in de onderneming plaatsvindt, groot zal zijn. Deze invloed zal zich primair het sterkst manifesteren op de lagere leidinggevende niveau's.

\section{De invloed op de besturing}

Automatisering heeft geen invloed op de ,objectives of the firm” maar vergroot wel in bijzondere mate de mogelijkheden tot verwezenlijking van de doelstellingen. Door het gebruik van de computer kunnen de verschillende keuzeproblemen die in de onderneming voorkomen op een meer exacte wijze worden gesteld en opgelost. Dit eist een volkomen andere instelling van degenen, die beslissingen moeten voorbereiden en nemen. Men zal de bereidheid moeten hebben in een vroeg stadium problemen te onderkennen en kwantitatief te formuleren. Daarnaast is er de noodzaak van exacte formulering van de beslissingsregels die in verschillende situaties zullen moeten gelden. Worden deze procedures en de kwantitatief geformuleerde problemen in een computersysteem opgenomen dan worden in feite potentiële beslissingen voor reeksen van toekomstige gebeurtenissen genomen.

„Reporting by exception”, d.w.z. zodanige wijze van beleidsinformatie dat uitsluitend significante afwijkingen van de vastgestelde beleidslijnen worden gesignaleerd, zal in belangrijke mate toepassing kunnen vinden. De computer stelt n.l. in staat tot een snelle vergelijking van werkelijkheid en geprogrammeerde standaards of normen. Om te voorkomen dat alle verschillen tussen werkelijkheid en norm worden gesignaleerd - en dus ook die waarop geen actie behoeft te worden genomen - is het nodig in het computersysteem z.g. regelgrenzen op te nemen.

Simulatie van produktieprocessen en van het proces van beslissingen is eerst goed mogelijk geworden door de inschakeling van computers. Simulatie is een belangrijk hulpmiddel bij de beslissingsvoorbereiding en de besluitvorming.

Middelen om de doelmatigheid van het beslissen te vergroten zijn $0 . a .{ }^{24}$ ):

a. vergroting van de kennis omtrent de processen die bepalend zijn voor de omgeving waarin bepaalde beslissingen worden genomen

b. verbetering van beslissingsprocessen als zodanig

${ }^{24)}$ T. J. Bezemer: Simulatie van beslissingen. Management-aspecten van de automatisering, Het Spectrum: 1965.

m a b blz. 30 
c. overdracht van de uitvoering van, althans een deel van beslissingsprocesssen, aan machines.

Simulatie is hierbij een belangrijk hulpmiddel omdat her de mogelijkheden tot toetsing van modellen, waarin de samenhang van factoren en verschijnselen is geformuleerd, in zeer belangrijke mate vergroot.

Ter afronding van het voorgaande willen wij ook wijzen op hetgeen Leavitt ${ }^{25}$ ) zegt over de veranderende instelling van de leiding: ,Managing will probably be a much more analytic job than it has been in the past, much more a scientific operation than a seat-of-the-pants one".

\section{De invloed op de organisatie}

De versnelling en verbetering van informatie, het inbouwen van formele beslissingen en de ,reporting by exception" welke het gevolg zijn van de bestuurlijke automatisering, zal de ,span of attention” van de leiding belangrijk vergroten. Het traditionele onderscheid tussen lijn en staf zal vervagen daar zoals Leavitt reeds heeft opgemerkt management een meer wetenschappelijk karakter krijgt. De functionele bevoegdheid tot het geven van dwingende aanwijzingen omtrent de te volgen werkwijze en uitvoeringsprocedures aan functionarissen die niet hierarchisch ondergeschikt zijn kan dientengevolge in belangrijkheid de lijnbevoegdheid gaan overheersen. Een scherpere scheiding zal ontstaan tussen enerzijds beheersaktiviteiten en anderzijds uitvoerende werkzaamheden, omdat vooral op de lagere niveau's in de organisatie de beslissingen door de computer zullen worden genomen.

Structuurwijzigingen zullen zich ook voordoen in de personeelsopbouw. Automatisering leidt nl. in vele sectoren van het bedrijf tot een substitutie van menselijke arbeid door machinale arbeid. Anderzijds ontstaan nieuwe functies zowel ten behoeve van de automatisering als zodanig alsook ter ondersteuning van beheersaktiviteiten. Het verschuivingsproces van ,blue-collar work" naar ,, whitecollar work" dat reeds direkt na de tweede wereldoorlog is ingezet, zal hierdoor nieuwe impulsen krijgen.

De geschetste ontwikkelingen zullen op de administratie, die op het gebied van de informatieverzorging een belangrijke rol speelt, eveneens grote invloed hebben. Het accent zal bij de menselijke arbeid veel meer op preparation, interpretation and recommendation komen te liggen, dan op operation. Wij moeten de computer dan ook niet zien als een bedreiging, maar veeleer als een enorme uitdaging, dic voor ons nieuwe mogelijkheden opent om de verworvenheden van de bedrijfseconomie nu ook metterdaad in de praktijk toe te passen.

25) Harold J. Leavitt: Managerial Psychology, The University of Chicago Press: 1965. 